\title{
To Pay or Not to Pay? Business Owners' Tax Morale: Testing a Neo-Institutional Framework in a Transition Environment
}

\author{
Tomasz Mickiewicz ${ }^{1}$ Anna Rebmann ${ }^{2}$ (1) Arnis Sauka ${ }^{3}$
}

Received: 17 February 2016/Accepted: 23 June 2017/Published online: 18 July 2017

(C) The Author(s) 2017. This article is an open access publication

\begin{abstract}
In order to understand how the environment influences business owner/managers' attitudes towards tax morale, we build a theoretical model based on a neo-institutionalist framework. Our model combines three complementary perspectives on institutions-normative, cultural-cognitive and regulatory-instrumental. This enables a broader understanding of factors that influence business owner-managers' attitudes towards tax evasion. We test the resulting hypotheses using regression analysis on survey data on business owner/managers in Latvia-a transition country, which has undergone massive institutional changes since it was part of the Soviet Union over 25 years ago. We find that legitimacy of the tax authorities and the government (normative dimension), feeling of belonging to the nation (cultural-cognitive dimension) and perceptions of the risk and severity of punishment (regulatory-instrumental dimension) are all associated with higher tax morale for business owners and managers.
\end{abstract}

Keywords Entrepreneurship · Informal economy · Identity $\cdot$ Institutions $\cdot$ New institutionalism $\cdot$ Business owners/managers $\cdot$ Tax evasion $\cdot$ Tax morale $\cdot$ Trust

Anna Rebmann

a.rebmann@aston.ac.uk

Tomasz Mickiewicz

t.mickiewicz@aston.ac.uk

Arnis Sauka

arnis.sauka@sseriga.edu

1 Aston University and ESRC Enterprise Research Centre, Birmingham, UK

2 Aston University, Birmingham, UK

3 Stockholm School of Economics in Riga, Riga, Latvia

\section{Introduction}

In recent years, tax avoidance by businesses has attracted much media attention. Some large corporations have been in the news for employing tax avoidance schemes to legally avoid paying large amounts of tax. In turn, smaller-scale firms that aim to decrease their tax liabilities tend to rely on a different strategy: tax evasion by engaging in the informal economy/or not declaring all of their activities to the tax authorities. It is the latter phenomenon which, due to its dispersed character, is less understood (Alm and McClellan 2012).

Several studies argue that such deviant forms of firm behaviour, such as tax evasion, while contributing to firm growth, can also bring some societal benefits (Sauka 2008; Davidsson and Wiklund 2001; Warren 2003). From a narrow utilitarian perspective, if the private sector spending is more efficient, the money should stay there (for discussion, see: Benk et al. 2015; Preobragenskaya and McGee 2016). However, such arguments can only be seen as describing a second-best outcome. Like rent seeking and litigation, tax evasion comes with a deadweight cost: resources are wasted both by firms in evading taxes and by the government in trying to identify and punish tax evaders. In the longer term, tax evasion may lead to a vicious circle, where a shrinking tax base falls on fewer businesses that comply fully, in turn pushing even more entrepreneurs into the informal economy. This leads to dual business structures: formal versus informal. This duality not only implies suboptimal choices of business strategies, but is also detrimental to the formation of high growth businesses (Estrin and Mickiewicz 2012). Under such a scenario, economic development both at the local and at the country level suffers.

In the rational choice explanation of tax evasion, the amount of tax an individual chooses to pay depends on the 
individual's (income-defined) expected utility of the benefits of not paying taxes, compared to the risk of being caught evading taxes and the cost of the consequent punishment (Allingham and Sandmo 1974; Yitzhaki 1974). However, one of the main conclusions from empirical research is that tax evasion is much lower than can be explained by expected utility defined in financial terms alone (see: Torgler 2003a; Feld and Frey 2010; and Torgler 2002 for overview of evidence from experiments). In this light, as emphasised by Alm and Torgler (2011), the central question in the tax evasion literature is not "why entrepreneurs evade taxes" but "why so many entrepreneurs pay taxes"- despite a relatively low likelihood of being caught evading accounted for the severity of punishment. To explain this discrepancy, the concept of tax morale-a moral obligation to pay taxes and "a belief in contributing to society by paying taxes" (Torgler and Schneider 2009, p. 230) — has gained relevance (Alm et al. 1992; Andreoni et al. 1998; Luttmer and Singhal 2014). Evidence indicates that at the aggregate level, countries with higher levels of tax morale have smaller shadow economies (Torgler and Schneider 2009; Halla 2012) and that individuals with higher levels of tax ethics are less likely to evade taxes (Blanthorne and Kaplan 2008; Wenzel 2005). The purpose of this paper is to analyse how the institutional context drives the tax morale of business owner/managers.

We contribute to the literature on tax morale in three ways. First, we aim to fill one particular gap in this literature where studies focusing on firms are still scarce (Alm and McClellan 2012) by empirically exploring potential determinants of the tax morale of business owner/managers. Much of the literature considers either tax morale or income tax evasion (a) by individuals (recent examples: McGee et al. 2015; Yew et al. 2015; Wei and McGee 2015; McGee et al. 2016) or (b) by large corporations (recent example: Jones and Temouri 2016). Yet most of the business activity falls between these two, in small- and medium-sized firms - on which we focus.

In empirical studies, self-employed and business owners have been found to have lower tax morale than other individuals (Alm et al. 2010; Lago-Peñas and Lago-Peñas 2010; Torgler 2003b, d, 2012; Yew et al. 2015). While these studies have shown that there are differences between the employed and self-employed, the data used in these studies on business owners and managers are limited and prevent greater focus on these individuals and the circumstances of their businesses. We have gathered data from 220 business owners and managers which allow us to explore focus on them and enable us to control for different business characteristics which may affect tax morale. Moreover, a direct focus on the owner/managers' tax morale is critical, given the role of owner/manager attitudes and intentions in shaping business strategies (Wiklund et al. 2003), including entrepreneurial activities that spill over into informality (Webb et al. 2009 Alm and McClellan 2012).

Our second contribution is that through focusing on tax morale in businesses, we can integrate the research on tax morale and the literature on informality. Informality is usually treated as a dichotomy: firms are either fully informal or fully formal. Thus, the literature on the informal economy distinguishes between those with either all legal or all illegal production of goods and services that is deliberately concealed from public authorities (Schneider et al. 2010). However, this strict division does not reflect reality; as De Castro et al. (2014) point out, there are many shades of grey in between. Companies may be often officially registered, yet in part adopt illegal means, say, illegal employment and related non-compliance in tax reporting (including not paying social insurance contributions). As emphasised by Webb et al. (2009), such cases are more difficult to detect than those of ventures that adopt illegal ends. Yet, by focusing on tax evasion and tax morale in business we can help shed light on this grey area and show how it is useful for these two literatures to be combined. Accordingly, we are interested in registered companies that follow legal ends (producing legal products), but may consider using illegal means to do so. In contrary to unregistered businesses that are illegal by definition, in legally registered businesses, owner/managers decide the extent to which they evade taxes and, as we argue in this paper, these choices are influenced by institutional systems.

While the role of the institutions in influencing tax morale has been explored previously (Cohen et al. 2015; Hanousek and Palda 2004; Hug and Spörri 2011; LagoPeñas and Lago-Peñas 2010; Torgler 2003b, c, 2012), our third contribution is to provide an integrated theoretical framework, which allows us to identify theoretically which are the critical institutional factors. This framework, inspired by Scott's (2014) new institutionalism, is adopted to explain how the environment influences the tax morale of business owner/managers. It combines three complementary perspectives on institutions-normative, culturalcognitive and regulatory-instrumental-allowing us to unpack different institutional factors affecting tax morale. It provides a broad perspective of how institutions can affect individuals. The institutions not only influence individual behaviour through sanctions as the regulatory perspective suggests, but also through affecting normative judgments by individuals on how things should be done. Furthermore, institutions provide cultural-cognitive frameworks; individuals adopt specific (and multiple) social identities that define their roles and in turn constrain how individuals behave by not even considering any other behaviour as it contradicts what is taken for granted (Scott 2014, p. 44; 68). 
Last but not least, our contribution is in applying this framework in the context of a transition economy. Latvia, being a transition country with a multi-ethnic make-up, provides an environment with great institutional heterogeneity on the institutional variables. Our choice to draw on the data from a transition country is informed by the proposition that such countries are a good fit for analysing the impact of the environment on tax morale (Torgler 2003d; Alm et al. 2006; McGee et al. 2015; Yew et al. 2015; Preobragenskaya and McGee 2016). Latvia has undergone huge institutional changes in the last 25 years, transitioning from a command economy when it was part of the Soviet Union, back to independence with a market economy and now becoming integrated into the European Union. As Torgler (2003a) and Alm et al. (2006) explain, this kind of transition requires a major transformation in the tax system, including the implementation of direct taxation of firms and individuals. Moreover, as we will discuss further below, the characteristics of the command economy under the Soviet Union might have created strong grounds for distrust and dissatisfaction with the government. Such attitudes are not likely to change fast and thus might still persist in Latvia two decades after the start of the transition process (Putnins and Sauka 2015, 2016). Thus, in transition countries like Latvia, all the three elements of institutional frameworks (normative, cognitive and regulatory) are evolving and may affect different owner/managers in dissimilar ways, generating heterogeneity that is of interest for empirical research.

The paper is structured as follows: the next section introduces the conceptual framework for analysing determinants of tax morale. We then proceed with describing the methodology - a survey of owner/managers, which is followed by the results sections. The paper concludes with conclusions and implications.

\section{Determinants of Tax Morale: A Framework}

This section presents the theoretical framework for the study. We adopt categories introduced by the new institutionalism which are framed as the three "institutional pillars", or complementary institutional perspectives (Scott 2014).

Scott (2014, p. 33) defines institutions as “...cognitive, normative, and regulative structures and activities that provide stability and meaning to social behaviour". These different facets of institutions shape the norms adopted by individuals and affect their behaviour. Each system provides a different mechanism for compliance (or non-compliance) with the institutional framework. Seeking to explain tax morale, we will describe (1) the normative mechanisms as those that may generate social obligation based on norms seen as legitimate, (2) the cognitive mechanisms as representing adoption of social identities with a corresponding behaviour that is seen as the way to act and (3) regulatory mechanisms that affect an individual through perceived sanctions. All individuals and firms are confronted and shaped by institutions via these three different mechanisms, even if the institutional environment is often not uniform in the way it affects them (Scott 2014).

This theoretical framework of the study is summarised in Fig. 1. The relational institutional systems, in which business owner/managers (entrepreneurs) are embedded, influence their tax morale, i.e. their attitudes towards tax evasion, via the three institutional aspects discussed above (normative, cognitive and regulatory).

Institutions have been studied in tax morale literature previously as can be seen in Table 1 below in which we present empirical studies from 2007-2016 which have included an analysis of institutions. However, by using Scott's framework and by bringing the three perspectives
Fig. 1 Theoretical framework

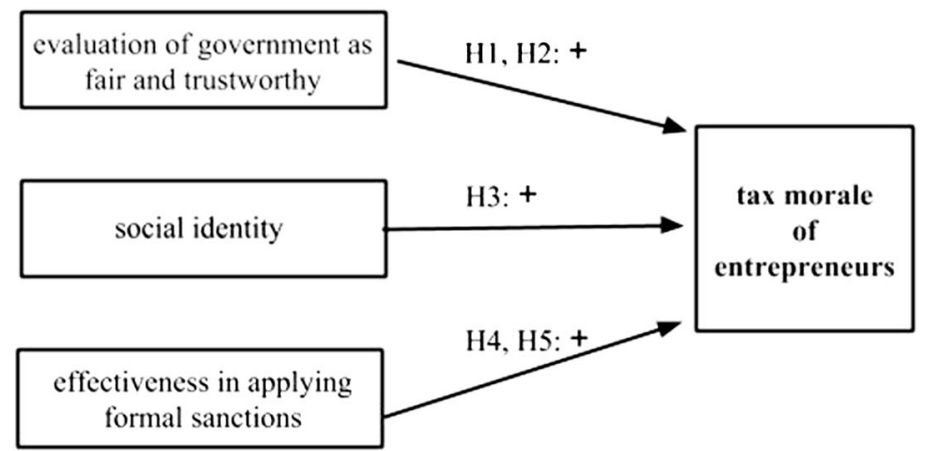


Table 1 A selection of studies from 2007 to 2016 including institutional variables to explain tax morale

\begin{tabular}{|c|c|c|c|c|c|}
\hline Reference & Dependent variable & Institutional dimensions & $\begin{array}{l}\text { Sample and } \\
\text { econometrics }\end{array}$ & Source of data & Findings \\
\hline $\begin{array}{l}\text { Konrad and } \\
\text { Qari } \\
(2012)\end{array}$ & $\begin{array}{l}\text { Tax compliance: "How } \\
\text { important is it never to } \\
\text { try to evade taxes" }\end{array}$ & Patriotism & $\begin{array}{l}\text { Individuals in eight } \\
\text { countries. OLS and } \\
\text { ordered probit }\end{array}$ & $\begin{array}{l}\text { International } \\
\text { social survey } \\
\text { programme } \\
2004 \text { and } \\
2003\end{array}$ & $\begin{array}{l}\text { Positive association } \\
\text { between tax compliance } \\
\text { and patriotism }\end{array}$ \\
\hline $\begin{array}{l}\text { Torgler } \\
\text { (2012) }\end{array}$ & $\begin{array}{l}\text { Tax morale: always or } \\
\text { never justified-cheating } \\
\text { on tax payments if you } \\
\text { get the chance }\end{array}$ & $\begin{array}{l}\text { Trust in government; trust } \\
\text { in justice system; trust in } \\
\text { EU; governance quality; } \\
\text { religiosity }\end{array}$ & $\begin{array}{l}\text { Individuals in ten } \\
\text { Eastern European } \\
\text { countries that } \\
\text { joined the } \\
\text { European Union by } \\
\text { 2007. Weighted } \\
\text { ordered probit }\end{array}$ & $\begin{array}{l}\text { European } \\
\text { values survey } \\
1999 / 2000 \\
\text { and } 2008\end{array}$ & $\begin{array}{l}\text { All institutional variables } \\
\text { positively related to tax } \\
\text { morale }\end{array}$ \\
\hline $\begin{array}{l}\text { Heinemann } \\
\text { (2011) }\end{array}$ & $\begin{array}{l}\text { Tax morale: always or } \\
\text { never justified-cheating } \\
\text { on tax payments if you } \\
\text { get the chance }\end{array}$ & $\begin{array}{l}\text { Economic crisis; } \\
\text { generosity of welfare } \\
\text { system; confidence in } \\
\text { parliament; patriotism }\end{array}$ & $\begin{array}{l}\text { Individuals in } 20 \\
\text { OECD countries. } \\
\text { Probit }\end{array}$ & $\begin{array}{l}\text { World values } \\
\text { survey-four } \\
\text { waves from } \\
1981 \text { to } 2003\end{array}$ & $\begin{array}{l}\text { Presence of economic } \\
\text { crisis and more generous } \\
\text { welfare systems are } \\
\text { associated with lower tax } \\
\text { morale and the two } \\
\text { interact to reinforce this } \\
\text { relationship. Confidence } \\
\text { in parliament and } \\
\text { patriotism is positively } \\
\text { related to tax morale }\end{array}$ \\
\hline $\begin{array}{l}\text { Hug and } \\
\text { Spörri } \\
(2011)\end{array}$ & $\begin{array}{l}\text { Tax morale: always or } \\
\text { never justified-cheating } \\
\text { on tax payments if you } \\
\text { get the chance. }\end{array}$ & $\begin{array}{l}\text { Trust in parliament, } \\
\text { government, legal } \\
\text { system; satisfaction with } \\
\text { political system and } \\
\text { incumbents; referendum } \\
\text { required for taxes }\end{array}$ & $\begin{array}{l}27 \text { countries. Multi- } \\
\text { level ordered probit }\end{array}$ & $\begin{array}{l}\text { World values } \\
\text { survey } \\
\text { 1995-1997 }\end{array}$ & $\begin{array}{l}\text { Some evidence that trust } \\
\text { positively related to tax } \\
\text { morale. Incumbent } \\
\text { satisfaction is positively } \\
\text { related to tax morale. } \\
\text { Referendum institutions } \\
\text { do not have a direct } \\
\text { effect on the level of tax } \\
\text { morale across countries }\end{array}$ \\
\hline $\begin{array}{l}\text { Marien and } \\
\text { Hooghe } \\
(2011)\end{array}$ & $\begin{array}{l}\text { Legal permissiveness- } \\
\text { scale from whether it is } \\
\text { always or never justified } \\
\text { to cheat on tax, pay cash } \\
\text { to avoid sales tax and } \\
\text { claim benefits to which } \\
\text { you are not entitled }\end{array}$ & $\begin{array}{l}\text { Political trust-a scale } \\
\text { made from trust in } \\
\text { parliament, the justice } \\
\text { system, the armed forces } \\
\text { and the police; } \\
\text { religiosity; moral } \\
\text { conservatism }\end{array}$ & $\begin{array}{l}\text { Individuals in } 33 \\
\text { European countries. } \\
\text { Multi-level } \\
\text { multinomial logit }\end{array}$ & $\begin{array}{l}\text { European } \\
\text { values survey } \\
\text { 1999-2001 }\end{array}$ & $\begin{array}{l}\text { Political trust, religiosity } \\
\text { and moral conservatism } \\
\text { are negatively related to } \\
\text { legal permissiveness }\end{array}$ \\
\hline $\begin{array}{l}\text { Torgler } \\
\text { et al. } \\
(2010)\end{array}$ & $\begin{array}{l}\text { Tax morale: always or } \\
\text { never justified-cheating } \\
\text { on tax payments if you } \\
\text { get the chance }\end{array}$ & $\begin{array}{l}\text { Quality of governance } \\
\text { index (World Bank); } \\
\text { trust in parliament, trust } \\
\text { in justice system }\end{array}$ & $\begin{array}{l}\text { Individuals in } 30 \\
\text { European countries. } \\
\text { Ordered probit } \\
\text { model }\end{array}$ & $\begin{array}{l}\text { European value } \\
\text { survey } \\
1999 / 2000\end{array}$ & $\begin{array}{l}\text { All institutional } \\
\text { dimensions significant }\end{array}$ \\
\hline $\begin{array}{l}\text { Lago-Peñas } \\
\text { and Lago- } \\
\text { Peñas } \\
(2010)\end{array}$ & $\begin{array}{l}\text { Tax morale: "citizens } \\
\text { should not cheat on their } \\
\text { taxes" }\end{array}$ & $\begin{array}{l}\text { Trust in politicians; } \\
\text { satisfaction with } \\
\text { democracy; ethnic } \\
\text { fractionalisation }\end{array}$ & $\begin{array}{l}\text { Individuals in } 17 \\
\text { European countries. } \\
\text { Multi-level } \\
\text { weighted ordered } \\
\text { logistic regression }\end{array}$ & $\begin{array}{l}\text { European social } \\
\text { survey } \\
\text { 2004-2005 }\end{array}$ & $\begin{array}{l}\text { Tax morale is stronger } \\
\text { with greater trust in } \\
\text { politicians and greater } \\
\text { satisfaction with } \\
\text { democracy. Ethnic } \\
\text { fractionalisation reduces } \\
\text { tax morale }\end{array}$ \\
\hline $\begin{array}{l}\text { Martínez- } \\
\text { Vázquez } \\
\text { and } \\
\text { Torgler } \\
\text { (2009) }\end{array}$ & $\begin{array}{l}\text { Tax morale: always or } \\
\text { never justified-cheating } \\
\text { on tax payments if you } \\
\text { get the chance }\end{array}$ & $\begin{array}{l}\text { Trust in the parliament; } \\
\text { religiosity; national pride }\end{array}$ & $\begin{array}{l}\text { Individuals in Spain. } \\
\text { Weighted ordered } \\
\text { probit estimation }\end{array}$ & $\begin{array}{l}\text { World values } \\
\text { survey and } \\
\text { European } \\
\text { values survey: } \\
\text { 1981, 1990, } \\
1995 \text { and } \\
\text { 1999/2000 }\end{array}$ & $\begin{array}{l}\text { All institutional variables } \\
\text { are statistically } \\
\text { significant and positively } \\
\text { related to tax morale }\end{array}$ \\
\hline
\end{tabular}


Table 1 continued

\begin{tabular}{|c|c|c|c|c|c|}
\hline Reference & Dependent variable & Institutional dimensions & $\begin{array}{l}\text { Sample and } \\
\text { econometrics }\end{array}$ & Source of data & Findings \\
\hline $\begin{array}{l}\text { Blanthorne } \\
\text { and } \\
\text { Kaplan } \\
(2008)\end{array}$ & $\begin{array}{l}\text { Ethics of underreporting. } \\
\text { Scale created from items: } \\
\text { underreporting against } \\
\text { principles; morally } \\
\text { wrong; not ethically } \\
\text { wrong; dishonest; and } \\
\text { not feeling guilty if } \\
\text { underreport }\end{array}$ & $\begin{array}{l}\text { Social norms regarding } \\
\text { underreporting; } \\
\text { opportunity to } \\
\text { underreport }\end{array}$ & $\begin{array}{l}\text { Individuals in USA } \\
\text { with different } \\
\text { levels of } \\
\text { opportunity to } \\
\text { evade tax }\end{array}$ & Own survey & $\begin{array}{l}\text { Social norms that } \\
\text { underreporting unethical } \\
\text { judge underreporting as } \\
\text { more unethical. Low } \\
\text { opportunity taxpayers, } \\
\text { who cannot easily benefit } \\
\text { personally from evasion, } \\
\text { judged evasion as more } \\
\text { unethical than high } \\
\text { opportunity taxpayers }\end{array}$ \\
\hline $\begin{array}{c}\text { Frey and } \\
\text { Torgler } \\
(2007)\end{array}$ & $\begin{array}{l}\text { Tax morale: always or } \\
\text { never justified-cheating } \\
\text { on tax payments if you } \\
\text { get the chance }\end{array}$ & $\begin{array}{l}\text { Trust in justice system, } \\
\text { parliament; satisfaction } \\
\text { with democracy; } \\
\text { institutional quality }\end{array}$ & $\begin{array}{l}\text { Individuals in } 30 \\
\text { West and East } \\
\text { European countries. } \\
\text { Weighted ordered } \\
\text { probit; clustered } \\
\text { standard errors }\end{array}$ & $\begin{array}{l}\text { European } \\
\text { values survey } \\
1999 / 2000\end{array}$ & $\begin{array}{l}\text { All institutional variables } \\
\text { are positively related to } \\
\text { tax morale }\end{array}$ \\
\hline $\begin{array}{l}\text { Torgler and } \\
\text { Schneider } \\
(2007)\end{array}$ & $\begin{array}{l}\text { Tax morale: always or } \\
\text { never justified-cheating } \\
\text { on tax payments if you } \\
\text { get the chance }\end{array}$ & $\begin{array}{l}\text { Trust in political } \\
\text { institutions and } \\
\text { government; attitudes } \\
\text { towards democracy; } \\
\text { direct democracy; } \\
\text { deterrence factors: fine } \\
\text { rate and audit } \\
\text { probability; national } \\
\text { pride; church attendance; } \\
\text { language }\end{array}$ & $\begin{array}{l}\text { Individuals in } \\
\text { Belgium, Spain and } \\
\text { Switzerland. } \\
\text { Weighted ordered } \\
\text { probit estimation }\end{array}$ & $\begin{array}{l}\text { World values } \\
\text { survey } \\
1995-1997 \\
\text { and the } \\
\text { European } \\
\text { values survey } \\
\text { 1999-2000 }\end{array}$ & $\begin{array}{l}\text { All trust variables, pro- } \\
\text { democratic attitudes, } \\
\text { national pride are } \\
\text { positively related to tax } \\
\text { morale. Direct } \\
\text { democracy positively } \\
\text { related to tax morale in } \\
\text { Switzerland, but } \\
\text { deterrence factors have } \\
\text { little effect. Religiosity is } \\
\text { only significant in } \\
\text { Belgium and } \\
\text { Switzerland. There are } \\
\text { some statistically } \\
\text { significant differences in } \\
\text { tax morale across } \\
\text { different language groups }\end{array}$ \\
\hline
\end{tabular}

(normative, cognitive and regulatory) on institutions together for the first time, we offer a more systematic view on the multiple channels through which institutions can affect tax morale. Next, we explore each aspect in more detail and present our hypotheses.

\section{Normative Perspective: Evaluation of the Government}

\section{The Theoretical Framework: The Normative Perspective}

We relate the normative channel affecting tax morale and tax evasion to business owner/managers' evaluation of the legitimacy and performance of political institutions, the government and the tax authority. Paying taxes is a social obligation towards the state. Citizens pay taxes to support the state in order to receive benefits; the state, however, is expected to act in a trustworthy and fair manner, a logic that Frey and Torgler (2007) label as "conditional cooperation".

Propensity to cooperate and to comply with prescribed behaviour is affected by a sense of obligation (Murphy 2004), which is always either enhanced or reduced conditional on the evaluation of the institution to which it relates. Taxes are an obligation paid to the state through the tax office providing money to be spent by the government. Positive evaluation of state administration makes the business owner/manager more likely to adopt a cooperative strategy towards it (Marien and Hooghe 2011; Hug and Spörri 2011; De Castro et al. 2014). Paying taxes in full is the key feature of such strategic choice, as it implies giving back to the community via an intermediary authority that the individual values and therefore sees its claims as legitimate. However, if an individual does not consider the recipients of these taxes (the tax office and the government) trustworthy and honest, or does not believe the rules by which the tax revenue is collected and/or spent to be fair, this is likely to undermine a positive attitude towards full 
compliance and justify adopting a norm of non-compliance (Alon and Hageman 2013; Kavka 1983; Kirchler et al. 2008; Murphy 2004; Scholz and Lubell 1998). In such circumstances, the legitimacy of the government and of the tax office is weakened.

Thus, the positive evaluation of the government makes business owner/managers more likely to adopt cooperative strategies of full tax compliance. In particular, perceptions of the fairness of the government are important and are best achieved by a lack of arbitrariness and favouritism in the provision of government services. Poor practice of public administration may lead to corruption and favouritism. The latter may to some extent occur independently of the formal quality of the legal system, which may be simply disregarded by public servants. This possibility arises as the behaviour of administrators is affected both by formal frameworks and by informal norms, the latter tending to be persistent (North 1990; Williamson 2000; Estrin et al. 2013).

The authority of the government may be further undermined when the link between the state's provision of benefits to individuals and firms and their contribution in taxes is perceived as broken (Welter and Smallbone 2011; Alon and Hageman 2013). In this situation, firms may migrate either partly or entirely beyond the sphere of legality $^{1}$ to the informal economy. Yet in the latter case they may not be able to benefit from some of the government services, for example, gaining recourse to the law as the use of the courts requires some legal identity, which firms that operate entirely outside the legal sphere will not possess. This implies that a strategy of a partial rather than full migration into the illegal economy is far more likely as long as the government is not entirely dysfunctional and business owners/managers do not face a failed state where no public goods are effectively provided by the government (Acemoglu and Robinson 2012). Previous literature has found a positive relation of tax morale with trust in public officials (Torgler 2003b), with politicians and with overall satisfaction with the way the government and political system function (Lago-Peñas and Lago-Peñas 2010; Marien and Hooghe 2011; Scholz and Lubell 1998; Torgler et al. 2010). However, we stress the need to distinguish between the trust in government interpreted along the lines discussed above (rather than in politicians) and the specific impact of confidence in the tax system. We posit that both confidence in the government and more specifically in those aspects of government most directly related

\footnotetext{
${ }^{1}$ Here, the terminology developed by Webb et al. (2009) is adopted: informal economy implies that both means and ends remain legitimate, even if some elements within those are illegal (for instance, illegal employment and related non-compliance in tax payments). In contrast, socially illegitimate activities are labelled 'renegade economy'.
}

to taxes, such as the tax office and tax system, will affect the tax morale of business owner/managers. These relationships are expressed in terms of two hypotheses that can be tested empirically.

H1 Business owner/managers who express confidence in the government have higher tax morale.

H2 Business owner/managers who express confidence in the tax system as fair have higher tax morale.

\section{The Transition Context and the Normative Perspective: Evaluation of Government}

The development of trust in the government is challenging in institutional environments like Latvia, where government structures have been rebuilt after a long period of foreign occupation, or built from scratch. In such cases, a lack of government legitimacy is reinforced by persisting norms and values developed in the past, when government had long been perceived as imposed without societal consent. While newly formed political institutions may be initially endowed with social approval, there may also be incongruence between this potential approval and deeply ingrained attitudes of mistrust. More generally, Torgler (2003d) finds that nations such as Latvia, which were once incorporated into the Soviet Union, exhibit lower levels of tax morale compared to Central Eastern European "satellite" communist countries. In particular, within the latter group, East Germany has been characterised by an inherited high level of trust (Torgler 2003e).

It is likely that the logic of mistrust applies in particular to relations between the institutional actors representing the state and business owners/managers (Welter 2012). Ireland et al. (2008) stress how a communist legacy affects transitional economies via hostile attitudes towards entrepreneurship; these attitudes are also deeply ingrained in the practices of state officials, whose bureaucratic values were formed under the old regime. These old values may also continue to be reproduced within the government administration.

The deeper roots of transition economies' normative traits relate to the political-institutional tradition, which did not respect the autonomy of private enterprise, holding that the rights to any economic surplus belong to the political rulers who discretionarily licence limited rights to private entrepreneurs in a form of privilege (Pipes 2000; Estrin and Mickiewicz 2011). Within such a perspective, the distinction between the collection of taxes and corrupt extortion by politicians and administrators becomes blurred (Pipes 2000). Such a heritage of norms and values can only change gradually, undermining business owner/managers' positive evaluation of the government. Thus, at the interface between business owners/managers and the state 
bureaucracy, the mistrust on both sides persists, which may have the characteristics of a self-fulfilling prophecy whereby neither side perceives an obligation to act in a way that takes the interests of the other side into account.

In addition to longer-term factors, poor economic performance during the transition period has been an important factor further undermining legitimacy of the government and, therefore, tax morale (Torgler 2003a; Alm et al. 2006). In the context of our study, it is therefore quite relevant that Latvia was hit particularly badly by the global financial crisis. From 2003 to 2007, GDP average yearly growth was $9.7 \%$, but in 2009, GDP fell $18.0 \%$; in 2010, when the data for our study were collected, Latvia was still in recession with GDP growth at $-0.3 \%$ (World Bank Development Indicators). The severity of the economic crisis is likely to have impacted on tax morale in Latvia. Heinemann (2011) found that the incidence of economic crisis (as measured by severe jumps in the yearly unemployment rate) is negatively related to tax morale in OECD countries. The impact of economic crises across individuals and firms in a country is likely to be uneven, with some suffering much more than others. Some businesses could feel that what happened to them was unfair and their experiences during recession may have undermined the sense of reciprocity and solidarity that underpins tax compliance. Thus, the firm-level impact of the crisis may be negatively related to tax morale. Furthermore, taxation impacts on business profitability. Some individuals may choose to evade tax in order to avoid improve profitability. Hence, in analysing the tax morale of business owners and managers, we should take this contextual factor into account.

\section{Cognitive-Cultural Perspective: National Identification}

\section{The Theoretical Framework: The Cognitive Perspective}

The cultural-cognitive perspective draws upon anthropological approaches that "stress the centrality ... of the shared conceptions, which constitute the nature of social reality and create the frames through which meaning is made" (Scott 2014, p. 67). External cultural systems shape individuals' interpretation of their environment and provide guidance on how to act. Here, consistent with a link between cognition and attitudes (Fishbein and Ajzen 1975; Ajzen 2001; Mitchell et al. 2004), we stress that attitudes towards taxes are expected to be affected by the strength of the owner/manager's identification with the national polity: the shared concept of community linked to this polity motivates some individuals to pay taxes as a way of contributing to the community.

Consistent with this, payment of taxes may be driven by the social identity (Ashforth and Mael 1989; Hogg and Terry 2000) adopted by the owner/manager in particular the owner/manager's identification with the country to which they pay taxes. Social identity implies that individuals see themselves as members of a wider social group and in their behaviour adopt the perspective of that group (Hogg et al. 1995; Stets and Burke 2000). At a deep level of identification, some forms of cooperative behaviour become "taken for granted" and are no longer questioned; in contrast, loose identification implies that non-compliance is more likely (Scott 2014). Studies on tax morale have found that indicators of social identity, such as patriotism and nationalism, are positively associated with tax morale (Heinemann 2011; Konrad and Qari 2012; Martínez-Vázquez and Torgler 2009); however, community belonging may be considered a broader form of identification with the national polity. As well as the identification with the country that community belonging entails, patriotism also involves love of one's country, special concern for its well-being, linked with a willingness to sacrifice for the good of the country (Nathanson 1989). Nationalism is similar to patriotism, but the former rejects out-groups and the latter is more inclusive (Konrad and Qari 2012) and community belong is more inclusive still as more people are likely consider themselves as belonging to a community than to identify as patriots or nationalists. While patriotism and nationalism may be even more likely to promote tax morale than community belonging because they imply a more fervent attachment to the nation, we argue that it is the key aspect for tax morale is identification with the country. Accordingly, we emphasise the importance of community belonging and it is hypothesised that:

H3 Owner/managers who identify more strongly with their country have higher tax morale.

\section{The Transition Context and the Cognitive Perspective: National Identity}

Building a layer of social identity related to the state and national polity may be particularly difficult in transition countries, especially those, like Latvia, which regained statehood or were created from scratch. Between 1918 and 1940, the newly created state of Latvia experienced a period of independence only to be annexed into the Soviet Union in 1940 as a result of a pact between Stalin and Hitler. Latvia regained independence in 1991. However, due to this history, the population of Latvia consists of two main ethnic groups: Latvians and Russians. Although 
nowadays considered an ethnic minority, Russians living in Latvia were not so considered between 1940 and 1991. During that time, they were living in the Soviet Union, where Russian was the official language and where Russians were the dominant ethnic group. When Latvia became independent, this changed completely. This historical context provides challenges in building an inclusive Latvian national identity (Putnins and Sauka 2015, 2016).

Ireland et al. (2008) discuss how political identity is built via political parties. They accentuate a possibility that a programme of emphasising national identity may be hijacked by populist movements leading to effects and policies that are undesirable from the business and economic point of view. This is obviously more dangerous when this identity becomes affiliated with some ethnic criteria, leading to marginalisation of some minority groups and their dis-identification. While these dangers are very real, at the other end of the spectrum is the situation where building an elementary identification with the national polity becomes a challenge. Miller (2000) emphasises the positive benefits of national identity and solidarity, as long as these respect the lower-layer separate identities of minority groups. Where successful, such a model of democratic polity leads to strong identity with the nation and active citizenship, including business. In turn, this implies that obligations towards the government are respected and taxes are paid rather than avoided, which adds to the arguments supporting Hypothesis 3 above.

\section{Regulatory/Instrumental Perspective: Deterrence}

\section{The Theoretical Framework: The Regulatory Perspective}

Next, the regulatory-instrumental institutional perspective focuses on the regulatory role of institutions-that is on the role of formal institutions in shaping effective, explicit constraints on human behaviour. Within this context, attention is given to explicit regulatory processes-rulesetting, monitoring and sanctioning activities (Scott 2014). "The institutional logic underlying the regulatory pillar is an instrumental one: individuals conform to laws and rules because they seek the attendant rewards or wish to avoid sanctions" (Scott 2014, p. 62, 63). It is for this reason that this perspective is typically adopted by institutional economics (Williamson 2000) and, more broadly, by rational choice theory scholars (Becker 1968). As applied to tax evasion by business owner/managers, the regulatory-instrumental perspective implies a calculation of the costbenefits of non-compliance compared to paying tax.

The literature normally views tax morale as an ethical characteristic, which influences tax compliance independently of the effect of deterrence factors. However, Heinemann (2011) and Blanthorne and Kaplan (2008) argue that tax morale may be affected by an egocentric/self-serving bias whereby people adjust their attitudes according to their self-interest. In this way, deterrence factors may influence the tax morale. This is consistent with empirical results obtained by Blanthorne and Kaplan (2008) that tax payers have lower tax morale in occupations where they are more likely to have an opportunity to evade taxes than individuals with less opportunity for evasion. Thus, while arguments related to deterrence are well rehearsed, our application of those to the question of tax morale is more novel. We argue that individuals' costbenefit analysis of the deterrence factors against tax evasion influences their tax morale as individuals typically suffer from a self-serving bias whereby people adjust their norms/attitudes according to their self-interest.

It is also important to keep in mind that perceptions matter. Individuals hardly ever know the actual probabilities associated with enforcement of sanctions for noncompliance; thus, their perceptions are based on their local experience. There may also be a considerable lag in the way these perceptions respond to changes in tax administration practice, an issue we will return to when discussing the Latvian context.

Furthermore, perceptions about deterrence need not have one-to-one correspondence with reality. Scholz and Pinney (1995) argue that citizens who systematically overestimate the likelihood of getting caught by the Inland Revenue Service if they cheat also report a greater commitment to tax laws (duty to pay taxes). Similarly, Alm et al. (1992) find evidence in experimental data that some individuals overweight the probability of being caught, which to some extent explains the level of tax compliance. It is likely that risk-averse individuals will express cognitive bias perceiving the magnitude of punishment as higher than actually observed in reality. Furthermore, it seems plausible to assume that for more risk-averse individuals the cost of punishment weighs more heavily than for the less risk averse, which makes the distribution of outcomes more skewed even if not necessarily increasing the expected cost of punishment (where the latter is compensated by lower frequency of being caught). The juxtaposition of the impact of the likelihood of being caught and of the cost of punishment that we introduce in this context is novel. We posit that both aspects matter.

H4 Business owner/managers who perceive a greater likelihood of being caught evading tax are likely to have a higher tax morale.

H5 Business owner/managers who perceive tax evaders to be more severely punished when caught are likely to have higher tax morale. 


\section{The Transition Context and the Regulatory Perspective}

As discussed by Torgler (2003a) and Alm et al. (2006), under the Soviet system taxes were typically collected indirectly; in particular, revenue was transferred from state firms to other parts of government before wages were paid. With transition, the separation of economic activity from the state administration implied that the share of direct taxes increased significantly, including the introduction of individual tax returns (Alm et al. 2006). All this required radically new tasks for the state administration, for which it was not prepared. Implementing those reforms took significant time, during which a vacuum resulting from the implosion of the old regime was not yet fully replaced by modern tax administration, leading to low effectiveness in tax collection. Under such conditions, the significance of deterrence factors may be low.

Though our study has been conducted almost twenty years after transition started in Latvia, and tax administration in the Baltic republics improved much faster than in the rest of the former Soviet Union (Yew et al. 2015), it is likely that some of those phenomena may still have an impact. Moreover, it is not the actual effectiveness of the tax administration, but perceptions of its effectiveness that matter, as well as any additional significant lag in the latter adjusting to the change in the former.

\section{Methods}

\section{Data}

To demonstrate the theoretical framework and test its usefulness, the paper draws on a survey of business owner/managers conducted in Latvia in winter 2010. Information was obtained on all active firms in Latvia from the Orbis database maintained by Bureau Van Dijk. To achieve representativeness, size quintiles were formed (using book value of assets) and equal-sized random samples were taken from each size quintile. In total, 279 phone interviews were conducted, either in Latvian or Russian. Given the general mistrust in government discussed above, it was important that the study was conducted on behalf of an academic institution, as data collection by academics is met with a far more positive response from business owner/managers. Informed consent was obtained from all individual participants included in the study. The resulting sample consists of companies with a number of employees ranging from 1 to 300, with the median at 4 and the mean value of 15 employees; thus, it focuses on micro- and small-sized firms.
As tax evasion is a very sensitive topic, researchers have not yet achieved consensus on which methods are best suited to measuring the nature and the quantity of tax evasion behaviour. This study builds on the empirical approach of those previous studies that have used surveys and employed various techniques in order to gain more truthful responses. In particular, as suggested by Gërxhani (2007), a gradual approach is adopted, moving from less sensitive questions to more sensitive ones that deal with tax evasion. Also followed is the suggestion by Hanousek and Palda (2004) to frame the study as research on perceptions of government policy, not on tax evasion. Furthermore, as Sauka (2008) shows, interviewing by phone is an appropriate tool to explore tax evasion, particularly in environments where tax evasion is accepted behaviour, which is the case in Latvia (Torgler 2003d).

The dependent variable, tax morale, measures whether respondents think it is justifiable to cheat on tax if one has the chance. The question is taken from the World Values Survey (WVS) and has been used widely in research on tax evasion (see discussion in Torgler 2016). Marien and Hooghe (2011) show why applying direct questions about deviant behaviour leads to biased results, due to respondents' unwillingness to report it. Tax morale (alternatively labelled "legal permissiveness") is a more robust way to make inferences about tax evasion as it has been found to correlate highly with actual behaviour yet should be less subject to bias in reporting than asking directly if the individual evades taxes (Marien and Hooghe 2011, p. 274). The original response is measured on a ten-point Likert scale where 1 means the respondent thinks it is always justifiable and 10 means the respondent thinks it is never justifiable to evade tax (Table 2).

The first two hypotheses relate to the normative evaluation of both the government's spending of revenue collected via taxes and of the tax authorities' behaviour. For Hypothesis 1, a standard measure of trust in government is used, which again is copied from the WVS (see also: Marien and Hooghe 2011; Hug and Spörri 2011). For Hypothesis 2, Cronbach's alpha confirms that the best way to proceed is to aggregate the three individual questions related to trust in tax authorities into a three-item scale (Cronbach's alpha $=0.71$; details in Table 2).

To measure social identity (cultural-cognitive perspective) for Hypothesis 3, respondents were asked if "belonging to the Latvian community" is important to them, following Wenzel (2005). The word "community" is used instead of "nation" in order to try to capture a wider civic notion of identification with Latvia which can include ethnic Russians as well as ethnic Latvians. While in some countries the nation is seen as ethnically neutral and belonging to the nation is based on citizenship, in others 
Table 2 Variable descriptions and descriptive statistics

\begin{tabular}{|c|c|c|c|c|c|c|}
\hline Variable & Description & Mean & Median & SD & Min & Max \\
\hline $\begin{array}{l}\text { Tax morale (dependent variable } \\
\text { for OLS and ordered probit ten } \\
\text { models) }\end{array}$ & $\begin{array}{l}\text { Please tell me for the following statement whether you think it can } \\
\text { always be justified, never be justified or something in between: } \\
\text { "Cheating on tax if you have the chance": } 1 \text { means you think it is } \\
\text { always justifiable; } 10 \text { means you think it is never justifiable; and if } \\
\text { your views fall somewhere in between you can choose any } \\
\text { number in between }\end{array}$ & 6.10 & 6 & 2.63 & 1 & 10 \\
\hline Confidence in government & $\begin{array}{l}\text { How much confidence do you have in the government? } 4=\text { a great } \\
\text { deal, } 3=\text { quiet a lot, } 2=\text { not very much, } 1=\text { none at all (WVS) }\end{array}$ & 2.10 & 2 & 0.95 & 1 & 4 \\
\hline Confidence in tax authorities & $\begin{array}{l}\text { Scale formed from average answer to } 3 \text { statements: The state } \\
\text { revenue service: (1) is corrupt (reverse coded); (2) administers the } \\
\text { tax system fairly; (3) is generally honest in the way it deals with } \\
\text { people: } 5=\text { strongly agree } 1=\text { strongly disagree }\end{array}$ & 3.14 & 3.33 & 0.96 & 1 & 5 \\
\hline Community belonging & $\begin{array}{l}\text { Being a member of the Latvian community is important to me: } \\
5=\text { strongly agree } 1=\text { strongly disagree }\end{array}$ & 4.53 & 5 & 0.84 & 1 & 5 \\
\hline Chances of being caught & $\begin{array}{l}\text { Scale formed by adding respondent's assessment of chance of being } \\
\text { caught for each type of underreporting-business incomes, } \\
\text { number of employees, official salary levels. Chance of firm being } \\
\text { caught: } 1=\text { about } 0 \%, 2=\text { about } 25 \%, 3=\text { about } 50 \% \text {, } \\
4=\text { about } 75 \%, 5=\text { almost certain, } 100 \%\end{array}$ & 3.36 & 3 & 1.06 & 1 & 5 \\
\hline Severity of punishment & $\begin{array}{l}\text { If a firm did get caught seriously underreporting how severe are the } \\
\text { typical consequences: } 1=\text { not severe at all, minimal impact, } \\
2=\text { it will suffer some financial penalties, } 3=\text { it will suffer } \\
\text { serious financial penalties and become unprofitable, } 4=\text { it will } \\
\text { suffer serious financial penalties and may go out of business, } \\
5=\text { it will go out of business }\end{array}$ & 3.10 & 3 & 0.90 & 1 & 5 \\
\hline Female & Male $=0$, female $=1$ & 0.55 & 1 & 0.50 & 0 & 1 \\
\hline High education & Education: BA or higher $=1$ otherwise $=0$ & 0.29 & 0 & 0.45 & 0 & 1 \\
\hline Age & Age of respondent & 42.53 & 40 & 9.98 & 23 & 75 \\
\hline Latvian & Ethnicity of respondent Latvian $=1$, other ethnicity $=0$ & 0.79 & 1 & 0.41 & 0 & 1 \\
\hline No. of employees & Number of employees in 2010 & 14.11 & 5 & 28.80 & 1 & 245 \\
\hline Capital city & Firm based in capital Riga $=1$, based elsewhere in Latvia $=0$ & 0.56 & 1 & 0.50 & 0 & 1 \\
\hline Foreign share & Some foreign share in ownership & 0.03 & 0 & 0.18 & 0 & 1 \\
\hline Services & 1 or 0 & 0.57 & 1 & 0.50 & 0 & 1 \\
\hline Manufacturing & 1 or 0 & 0.09 & 0 & 0.28 & 0 & 1 \\
\hline Wholesale trade & 1 or 0 & 0.04 & 0 & 0.19 & 0 & 1 \\
\hline Retail trade & 1 or 0 & 0.19 & 0 & 0.39 & 0 & 1 \\
\hline Other sector & 1 or 0 & 0.10 & 0 & 0.30 & 0 & 1 \\
\hline Performance 2009-2010 & $\begin{array}{l}\text { Average of approximate } \% \text { change in three variables: net sales } \\
\text { profit, sales turnover, and employment in } 2010 \text { compared to } 2007 \text {. } \\
\text { Each of these variables is measured on a scale from } 1 \text { to } \\
5=\text { considerably increased: more than }+40 \%, 4=\text { increased: up } \\
\text { to }+40 \%, 3=\text { remained the same, } 2=\text { decreased: down to } \\
-40 \%, 1=\text { considerably decreased: more than }-40 \%\end{array}$ & 2.55 & 2.3 & 0.83 & 1 & 5 \\
\hline Performance 2007-2010 & Question same as above except compared to 2007 & 2.24 & 2 & 0.85 & 1 & 5 \\
\hline
\end{tabular}

such as Latvia, ethnicity plays a more prominent role in defining who is included in the nation (Björklund 2006). Nationalities are associated with ethnic groups-Latvian and Russian. This follows on from the Soviet era introduction of nationalities as an ethnic-based identity, which was allowed alongside being a citizen of the Soviet Union and provided the basis for creating republics within the Soviet Union (Kolstø 2000). Our survey instrument related to "Latvian community" may be seen as akin to those that assess different dimensions of the government (as discussed above, for $\mathrm{H} 1-\mathrm{H} 2$ ), yet the logic is different, being based on social identity theory, which is linked to the cognitive institutional perspective, as argued in the previous section.

For testing Hypothesis 4 (regulatory-instrumental aspects), a scale was constructed based on the respondent's assessment of the likelihood being caught not paying tax 
with respect to income (profits), number of employees and employees' salaries. Cronbach's alpha is 0.83 , indicating that these three items perform well as a scale. The scale, chances of being caught, is formed of the average of the respondent's assessment of chance of being caught for each type of underreporting-business incomes, number of employees, official salary levels and dividing by three. Finally, Hypothesis 5 is tested using a one-item Likert scale, severity of punishment, which simply asks about the respondent's perceptions of the severity of punishment. Details of all these measures are provided in Table 2.

Controls are included for respondent age, gender, ethnicity, education, business experience, change in firm performance from 2007 to 2010, as well as (alternatively) from 2009 to 2010, firm size (proxied by number of employees), regional fixed effects and sector fixed effects. For further details on the variables included in the estimation models, please see Table 2 .

There are further controls for gender, as according to previous findings women tend to have higher tax morale than men (Alm et al. 2010; Marien and Hooghe 2011), an effect attributed by Wei and McGee (2015) and Preobragenskaya and McGee (2016) to the way women are enculturated to defer to authority. Likewise, age is included, as older individuals are generally found to have higher tax morale (Frey and Torgler 2007; Alm et al. 2010; LagoPeñas and Lago-Peñas 2010; Torgler 2012; Preobragenskaya and McGee 2016). This effect may be weaker for transition economies, such as Latvia, as an age effect overlaps with generational effects-older respondents are more likely to retain attitudes learned under the Soviet period (Ireland et al. 2008; Estrin and Mickiewicz 2011). We include education as in earlier studies; however, the direction of the effect has been found to be either positive (Frey and Torgler 2007; Marien and Hooghe 2011; Yew et al. 2015), ambiguous (Alm et al. 2006) or negative (Lago-Peñas and Lago-Peñas 2010; Torgler 2006; Preobragenskaya and McGee 2016).

Respondents' ethnicity is included as a control as it may influence tax morale in Latvia due to the historical factors that formed the present day large Russian ethnic minority as described earlier. Due to this history, the Russian minority may have a different relationship with the Latvian state than ethnic Latvians, leading to lower tax morale. Respondents' ethnicity has not been included in previous research on tax morale; however, Lago-Peñas and Lago-Peñas (2010) found that individuals have a lower tax morale in countries with higher ethnic-linguistic fractionalisation.

To control for the impact of the economic crisis, a variable measuring the change in firm performance from 2009 to 2010 and from 2007 to 2010 is included. Performance is measured along three dimensions: changes in profit, sales turnover and employment. Each dimension is measured on a scale of one to five, with the average score for these three dimensions used as the measure of firm performance. Cronbach's alpha is 0.84 , indicating that these three dimensions perform well as a scale.

At the same time, there are arguments that suggest the opposite effect of performance on tax morale: an improvement in firm performance could also reduce tax morale. As performance increases, the opportunity cost of compliance becomes greater. Taking the view that norms have a self-serving bias, tax morale will fall as the opportunity cost of paying taxes (i.e. the opportunity cost of high tax morale) increases (Heinemann 2011). Increases in individuals' income have been found to be negatively related to tax morale in empirical studies (Heinemann 2011; Lago-Peñas and Lago-Peñas 2010; Torgler 2003c; Yew et al. 2015).

\section{Estimator and Specifications}

The dependent variable, tax morale, is ordinal and has a limited range of values running from 1 to 10 . This poses some problems for using OLS regression primarily because (1) distances between each category cannot be assumed to be equal and (2) OLS may product predicted values that fall outside the range of 1-10. Ordered probit models recognise that the categories of the dependent variable have an underlying ordering, but that the distances between adjacent categories are not known; these models also ensure that any predictions are limited to the range of the dependent variable (Greene and Hensher 2010; Long 1997). However, some econometricians still prefer OLS as the coefficients from ordered probit are much harder to interpret (Angrist and Pischke 2009). Consequently, many researchers with dependent variables that have 7 or more categories prefer to use OLS. In this study, for each specification coefficients are estimated using both OLS and ordered probit in order to ensure robustness as well as to aid interpretation of the results.

Post-estimation diagnostics do not indicate any cause for concern in using an OLS distribution. The residuals appear reasonably normally distributed; there is no evidence of skewness, nor of any severe outlying residuals, although kurtosis is a slight issue, as the distribution of the residuals is flatter than a normal distribution. However, the BreuschPagan test for heteroskedasticity does not reject the null of constant variance in the residuals. In any case, robust standard errors are applied in all specifications to ensure that the hypothesis tests are valid.

The robustness of the OLS results was checked by comparing them to results obtained from running an ordered probit model. When a 10-category version of the dependent variable, tax morale, was used for the ordered probit regressions, the data did not meet the parallel 
regression assumption that only the intercepts vary across the different categories (not reported but available on request). To overcome this problem, categories were combined to create a tax morale variable with three categories. This also has the added benefit of the results being easier to interpret. For the recoded version of tax morale, 1 represents individuals who think tax evasion is acceptable (initial responses 1-3), 2 represents those without strong feelings on the subject (responses 4-7), and category 3 represents individuals who believe that tax evasion is never acceptable (responses 8-10). As in ordered regression, the estimated slope parameters are assumed to remain the same across categories: combining adjacent categories should not affect the coefficients (Murad et al. 2003). The three-category dependent variable does not violate the parallel regressions assumptions of ordered probit, unlike the ten-category dependent variable. Furthermore, this recoding attenuates a potential measurement bias resulting from the fact that different individuals may attach different weight to the relative differences between categories. See Table 3 for coding details and summary statistics of the dependent variable.

While deciding on our models' specifications, we considered two further, standard empirical problems. The first is multicollinearity, while the second concerns the trade-off between the longer specification and the effective sample size. Multicollinearity was checked by calculating the variance inflation factors (VIFs). There was no evidence of its presence from the VIFs-the mean VIF was 1.13 and the maximum 1.25. However, in addition to VIFs, the model-specific underlying structure of correlations within the set of explanatory variables was explored further by calculating partial correlation coefficients (on which VIFs are based) for each of the key variables of interest. Not surprisingly, the two past performance measures for 2007-2010 and 2009-2010 are characterised by a high partial correlation coefficient of 0.71 . In addition, performance change in 2009-2010 and foreign share in ownership are also related, indicating that those firms responded to the crisis in a different way than domestic ones (partial correlation at 0.37 ). Multicollinearity between other variables did not seem to be an issue even when assessed by partial correlation coefficients.

The second problem relates to the high number of missing observations for past performance which reduces the effective sample size from 220 to 185 for 2009-2010 performance measures and even further reduces it to 159 for 2007-2010 performance measures.

Accordingly, several specifications of the model are presented (see Table 3). Model 1 includes only the control variables. Model 2 is extended by adding the institutional variables, which are the focus of this paper. It includes all explanatory variables except past performance, to take advantage of more information embedded in the larger sample size. Further tests include model 3 with the 2009-2010 performance measure and model 4 with the 2007-2010 performance measure. Models 3 and 4 come at the cost of a smaller sample size. As neither performance variable is statistically significant, model 2 is the preferred specification. The results of model 2 are robust to running on the smallest sample size-the 159 observations used to estimate model 4 . These results are reported in model 5.

\section{Results}

\section{Visualising the Results}

The complete results for all five models using both OLS and ordered probit for the 3-category measure of tax morale are presented in Table 4 . We report standardised beta coefficients for the OLS models to allow for comparison of effect sizes. The adjusted $R^{2}$ of the OLS model increases considerably from -0.01 in model 1 (which excludes the institutional variables) to 0.12 in model 2 (to which the institutional variables are added). While much of the variance is still left unexplained, this increase indicates the importance of institutional variables in explaining tax morale.

Another method of presenting the effects of the key independent variables on the dependent variable, tax morale (the 3-category version), in the ordered probit models is to plot the predicted probabilities of each category of tax morale for given values of a key independent variable, holding all the others fixed at their mean values (Greene and Hensher 2010; Long 1997). Predicted probabilities are calculated for an individual's level of tax morale for the three levels of tax morale, on the basis of estimates from model 2 in the regression table. These predictions are plotted in Fig. 2 which consists of four
Table 3 Recoding of dependent variable, tax morale, from ten categories to three categories with summary statistics of the three-category variable

\begin{tabular}{lllcc}
\hline Value & Meaning & WVS value & Frequency & Percent \\
\hline 1 & Tax evasion justifiable & $1-3$ & 41 & 18.6 \\
2 & & $4-7$ & 104 & 47.3 \\
3 & Tax evasion not justifiable & $8-10$ & 75 & 34.1 \\
$N=220$ & & & & \\
\hline
\end{tabular}


Table 4 Regression results: dependent variable tax morale

\begin{tabular}{|c|c|c|c|c|c|c|c|c|c|c|}
\hline & \multicolumn{2}{|l|}{ Model 1} & \multicolumn{2}{|l|}{ Model 2} & \multicolumn{2}{|l|}{ Model 3} & \multicolumn{2}{|l|}{ Model 4} & \multicolumn{2}{|c|}{ Model 5} \\
\hline & OLS & OP & OLS & OP & OLS & OP & OLS & OP & OLS & $\mathrm{OP}$ \\
\hline Trust in government & & & $\begin{array}{l}0.17 * * \\
(-0.17)\end{array}$ & $\begin{array}{l}0.18^{*} \\
(-0.08)\end{array}$ & $\begin{array}{l}0.15^{*} \\
(-0.19)\end{array}$ & $\begin{array}{l}0.14 \\
(-0.09)\end{array}$ & $\begin{array}{l}0.18^{*} \\
(-0.20)\end{array}$ & $\begin{array}{l}0.15+ \\
(-0.09)\end{array}$ & $\begin{array}{l}0.18^{*} \\
(0.20)\end{array}$ & $\begin{array}{l}0.15+ \\
(0.09)\end{array}$ \\
\hline Trust in tax administration & & & $\begin{array}{l}0.15+ \\
(-0.20)\end{array}$ & $\begin{array}{l}0.23^{*} \\
(-0.10)\end{array}$ & $\begin{array}{l}0.15+ \\
(-0.22)\end{array}$ & $\begin{array}{l}0.23^{*} \\
(-0.11)\end{array}$ & $\begin{array}{l}0.18^{*} \\
(-0.23)\end{array}$ & $\begin{array}{l}0.25 * \\
(-0.12)\end{array}$ & $\begin{array}{l}0.17 * \\
(0.23)\end{array}$ & $\begin{array}{l}0.24 * \\
(0.12)\end{array}$ \\
\hline Community belonging & & & $\begin{array}{l}0.17 * * \\
(-0.20)\end{array}$ & $\begin{array}{l}0.26^{* *} \\
(-0.10)\end{array}$ & $\begin{array}{l}0.13+ \\
(-0.21)\end{array}$ & $\begin{array}{l}0.23^{*} \\
(-0.11)\end{array}$ & $\begin{array}{l}0.12 \\
(-0.25)\end{array}$ & $\begin{array}{l}0.17 \\
(-0.12)\end{array}$ & $\begin{array}{l}0.13+ \\
(0.24)\end{array}$ & $\begin{array}{l}0.20+ \\
(0.12)\end{array}$ \\
\hline Likelihood caught & & & $\begin{array}{l}0.08 \\
(-0.17)\end{array}$ & $\begin{array}{l}0.12 \\
(-0.08)\end{array}$ & $\begin{array}{l}0.14+ \\
(-0.19)\end{array}$ & $\begin{array}{l}0.19^{*} \\
(-0.09)\end{array}$ & $\begin{array}{l}0.03 \\
(-0.22)\end{array}$ & $\begin{array}{l}0.11 \\
(-0.11)\end{array}$ & $\begin{array}{l}0.04 \\
(0.21)\end{array}$ & $\begin{array}{l}0.13 \\
(0.11)\end{array}$ \\
\hline Severity of punishment & & & $\begin{array}{l}0.15^{*} \\
(-0.18)\end{array}$ & $\begin{array}{l}0.21 * \\
(-0.09)\end{array}$ & $\begin{array}{l}0.15^{*} \\
(-0.20)\end{array}$ & $\begin{array}{l}0.21^{*} \\
(-0.09)\end{array}$ & $\begin{array}{l}0.19^{*} \\
(-0.21)\end{array}$ & $\begin{array}{l}0.26^{*} \\
(-0.10)\end{array}$ & $\begin{array}{l}0.18^{*} \\
(0.21)\end{array}$ & $\begin{array}{l}0.25^{*} \\
(0.10)\end{array}$ \\
\hline Female & $\begin{array}{l}-0.03 \\
(0.38)\end{array}$ & $\begin{array}{l}-0.14 \\
(0.17)\end{array}$ & $\begin{array}{l}-0.03 \\
(-0.35)\end{array}$ & $\begin{array}{l}-0.15 \\
(-0.17)\end{array}$ & $\begin{array}{l}-0.05 \\
(-0.38)\end{array}$ & $\begin{array}{l}-0.16 \\
(-0.19)\end{array}$ & $\begin{array}{l}-0.08 \\
(-0.41)\end{array}$ & $\begin{array}{l}-0.13 \\
(-0.20)\end{array}$ & $\begin{array}{l}-0.08 \\
(0.41)\end{array}$ & $\begin{array}{l}-0.14 \\
(0.20)\end{array}$ \\
\hline Age & $\begin{array}{l}0.09 \\
(0.02)\end{array}$ & $\begin{array}{l}0.01 \\
(0.01)\end{array}$ & $\begin{array}{l}0.07 \\
(-0.02)\end{array}$ & $\begin{array}{l}0.01 \\
(-0.01)\end{array}$ & $\begin{array}{l}0.06 \\
(-0.02)\end{array}$ & $\begin{array}{l}0.00 \\
(-0.01)\end{array}$ & $\begin{array}{l}0.07 \\
(-0.02)\end{array}$ & $\begin{array}{l}0.00 \\
(-0.01)\end{array}$ & $\begin{array}{l}0.07 \\
(0.02)\end{array}$ & $\begin{array}{l}0.00 \\
(0.01)\end{array}$ \\
\hline Higher education & $\begin{array}{l}0.09 \\
(0.42)\end{array}$ & $\begin{array}{l}0.25 \\
(0.18)\end{array}$ & $\begin{array}{l}0.02 \\
(-0.40)\end{array}$ & $\begin{array}{l}0.09 \\
(-0.19)\end{array}$ & $\begin{array}{l}0.03 \\
(-0.43)\end{array}$ & $\begin{array}{l}0.04 \\
(-0.21)\end{array}$ & $\begin{array}{l}0.05 \\
(-0.46)\end{array}$ & $\begin{array}{l}0.15 \\
(-0.22)\end{array}$ & $\begin{array}{l}0.04 \\
(0.46)\end{array}$ & $\begin{array}{l}0.11 \\
(0.22)\end{array}$ \\
\hline Ethnic Latvian & $\begin{array}{l}0.06 \\
(0.43)\end{array}$ & $\begin{array}{l}0.03 \\
(0.19)\end{array}$ & $\begin{array}{l}0.01 \\
(-0.45)\end{array}$ & $\begin{array}{l}-0.15 \\
(-0.22)\end{array}$ & $\begin{array}{l}-0.00 \\
(-0.48)\end{array}$ & $\begin{array}{l}-0.17 \\
(-0.24)\end{array}$ & $\begin{array}{l}0.03 \\
(-0.49)\end{array}$ & $\begin{array}{l}-0.11 \\
(-0.25)\end{array}$ & $\begin{array}{l}0.02 \\
(0.50)\end{array}$ & $\begin{array}{l}-0.15 \\
(0.25)\end{array}$ \\
\hline No. of employees & $\begin{array}{l}-0.05 \\
(0.00)\end{array}$ & $\begin{array}{l}-0.00 \\
(0.00)\end{array}$ & $\begin{array}{l}-0.07 \\
(0.00)\end{array}$ & $\begin{array}{l}0.00 \\
(0.00)\end{array}$ & $\begin{array}{l}-0.06 \\
(0.00)\end{array}$ & $\begin{array}{l}0.00 \\
(0.00)\end{array}$ & $\begin{array}{l}-0.05 \\
(0.00)\end{array}$ & $\begin{array}{l}0.00 \\
(0.00)\end{array}$ & $\begin{array}{l}-0.06 \\
(0.00)\end{array}$ & $\begin{array}{l}-0.00 \\
(0.00)\end{array}$ \\
\hline Capital city & $\begin{array}{l}0.05 \\
(0.39)\end{array}$ & $\begin{array}{l}0.00 \\
(0.17)\end{array}$ & $\begin{array}{l}-0.00 \\
(-0.39)\end{array}$ & $\begin{array}{l}-0.10 \\
(-0.18)\end{array}$ & $\begin{array}{l}-0.05 \\
(-0.42)\end{array}$ & $\begin{array}{l}-0.24 \\
(-0.19)\end{array}$ & $\begin{array}{l}-0.02 \\
(-0.44)\end{array}$ & $\begin{array}{l}-0.25 \\
(-0.20)\end{array}$ & $\begin{array}{l}-0.02 \\
(0.44)\end{array}$ & $\begin{array}{l}-0.24 \\
(0.20)\end{array}$ \\
\hline Foreign share & $\begin{array}{l}0.04 \\
(0.55)\end{array}$ & $\begin{array}{l}0.19 \\
(0.34)\end{array}$ & $\begin{array}{l}0.02 \\
(-0.40)\end{array}$ & $\begin{array}{l}0.1 \\
(-0.29)\end{array}$ & $\begin{array}{l}0.03 \\
(-0.44)\end{array}$ & $\begin{array}{l}0.15 \\
(-0.30)\end{array}$ & $\begin{array}{l}0.07 \\
(-0.63)\end{array}$ & $\begin{array}{l}0.53 \\
(-0.38)\end{array}$ & $\begin{array}{l}0.03 \\
(0.45)\end{array}$ & $\begin{array}{l}0.27 \\
(0.34)\end{array}$ \\
\hline Manufacturing & $\begin{array}{l}-0.05 \\
(0.86)\end{array}$ & $\begin{array}{l}-0.13 \\
(0.33)\end{array}$ & $\begin{array}{l}-0.04 \\
(-0.79)\end{array}$ & $\begin{array}{l}-0.11 \\
(-0.34)\end{array}$ & $\begin{array}{l}-0.02 \\
(-0.84)\end{array}$ & $\begin{array}{l}-0.01 \\
(-0.36)\end{array}$ & $\begin{array}{l}-0.01 \\
(-0.93)\end{array}$ & $\begin{array}{l}0.03 \\
(-0.42)\end{array}$ & $\begin{array}{l}-0.01 \\
(0.96)\end{array}$ & $\begin{array}{l}0.06 \\
(0.43)\end{array}$ \\
\hline Wholesale trade & $\begin{array}{l}0.10 \\
(1.16)\end{array}$ & $\begin{array}{l}0.99+ \\
(0.58)\end{array}$ & $\begin{array}{l}0.12 * \\
(-0.79)\end{array}$ & $\begin{array}{l}1.28 * * \\
(-0.44)\end{array}$ & $\begin{array}{l}0.12+ \\
(-0.82)\end{array}$ & $\begin{array}{l}1.26 * * \\
(-0.46)\end{array}$ & $\begin{array}{l}0.09 \\
(-0.89)\end{array}$ & $\begin{array}{l}1.04 * \\
(-0.50)\end{array}$ & $\begin{array}{l}0.11 \\
(0.84)\end{array}$ & $\begin{array}{l}1.16^{*} \\
(0.48)\end{array}$ \\
\hline Retail trade & $\begin{array}{l}0.03 \\
(0.46)\end{array}$ & $\begin{array}{l}0.07 \\
(0.20)\end{array}$ & $\begin{array}{l}0.02 \\
(-0.44)\end{array}$ & $\begin{array}{l}0.00 \\
(-0.21)\end{array}$ & $\begin{array}{l}0.01 \\
(-0.47)\end{array}$ & $\begin{array}{l}-0.03 \\
(-0.21)\end{array}$ & $\begin{array}{l}0.02 \\
(-0.50)\end{array}$ & $\begin{array}{l}-0.08 \\
(-0.22)\end{array}$ & $\begin{array}{l}0.03 \\
(0.50)\end{array}$ & $\begin{array}{l}-0.06 \\
(0.22)\end{array}$ \\
\hline Other sector & $\begin{array}{l}0.06 \\
(0.55)\end{array}$ & $\begin{array}{l}0.21 \\
(0.24)\end{array}$ & $\begin{array}{l}0.05 \\
(-0.55)\end{array}$ & $\begin{array}{l}0.18 \\
(-0.25)\end{array}$ & $\begin{array}{l}0.08 \\
(-0.62)\end{array}$ & $\begin{array}{l}0.49 \\
(-0.32)\end{array}$ & $\begin{array}{l}0.07 \\
(-0.62)\end{array}$ & $\begin{array}{l}0.35 \\
(-0.33)\end{array}$ & $\begin{array}{l}0.08 \\
(0.64)\end{array}$ & $\begin{array}{l}0.39 \\
(0.33)\end{array}$ \\
\hline $\begin{array}{l}\text { Performance change } \\
2009-2010\end{array}$ & & & & & $\begin{array}{l}-0.02 \\
(-0.22)\end{array}$ & $\begin{array}{l}-0.09 \\
(-0.10)\end{array}$ & & & & \\
\hline $\begin{array}{l}\text { Performance change } \\
2007-2010\end{array}$ & & & & & & & $\begin{array}{l}-0.10 \\
(-0.23)\end{array}$ & $\begin{array}{l}-0.17 \\
(-0.10)\end{array}$ & & \\
\hline Constant & $\begin{array}{l}4.32 * * * \\
(0.99)\end{array}$ & & $\begin{array}{l}-1.44 \\
(-1.33)\end{array}$ & & $\begin{array}{l}-0.72 \\
(-1.59)\end{array}$ & & $\begin{array}{l}-0.26 \\
(-1.78)\end{array}$ & & $\begin{array}{l}-1.10 \\
(1.58)\end{array}$ & \\
\hline Observations & 220 & 220 & 220 & 220 & 185 & 185 & 159 & 159 & 159 & 159 \\
\hline $\begin{array}{l}\text { Adjusted/pseudo- } R \text {-squared } \\
\text { Log-likelihood }\end{array}$ & -0.01 & $\begin{array}{l}0.02 \\
-222.4\end{array}$ & 0.12 & $\begin{array}{l}0.09 \\
-204.94\end{array}$ & 0.09 & $\begin{array}{l}0.11 \\
-171.4\end{array}$ & 0.11 & $\begin{array}{l}0.11 \\
-147.3\end{array}$ & 0.11 & $\begin{array}{l}0.10 \\
-148.2\end{array}$ \\
\hline
\end{tabular}

For OLS coefficients standardised betas are reported; OP $=$ ordered probit

Robust standard errors are reported in parentheses

$* * * p<0.001, * * p<0.01, * p<0.05,+p<0.10$ 
Fig. 2 Predicted probability plots for 3-category version of tax morale

\section{Predicted Probabilities \\ for the 3 category version of tax morale}
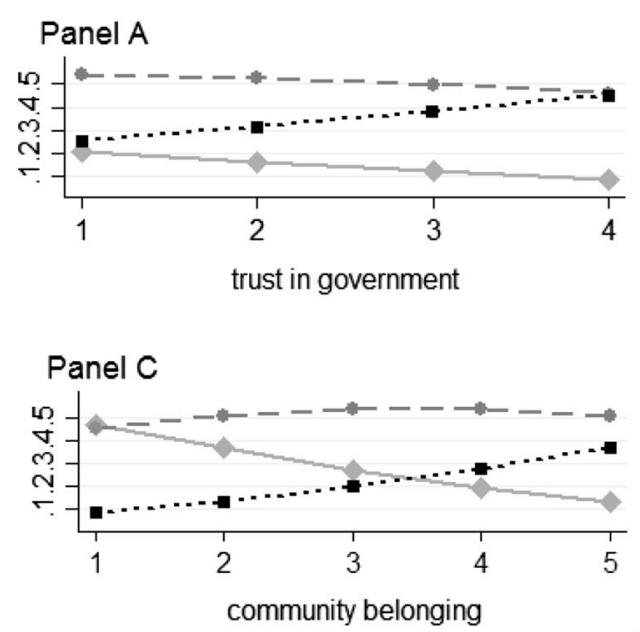

Panel B

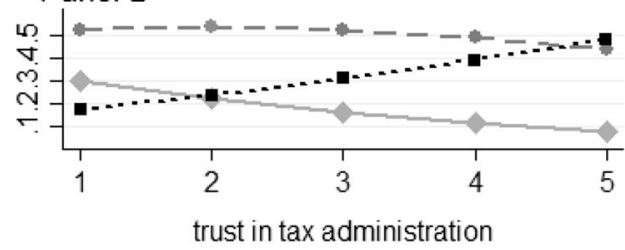

Panel D

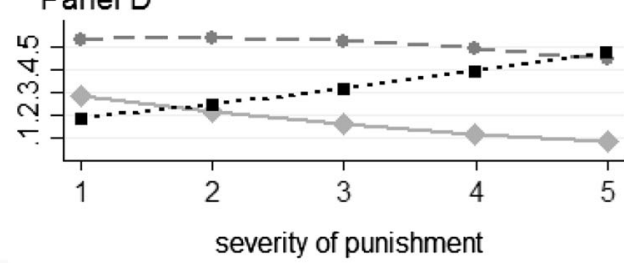

pr(tax evasion justifiable)

$\rightarrow \operatorname{pr}$ (no strong views on tax morale)

-. $\operatorname{pr}$ (tax evasion not justifiable)

graphs, one for each independent variable: trust in government, trust in tax administration, community belonging and severity of punishment, relevant for Hypotheses 1, 2, 3 and 4 . The plot shows how the probability of an average individual holding these views varies with a change in an independent variable. The horizontal axis indicates the value of the independent variable at which the predicted probability of the tax morale outcome is calculated. The vertical axis indicates the values of the predicted probabilities for each tax morale outcome. Each panel has three lines plotting the relationship between tax morale and the relevant independent variable. There is one line for each of the three categories of tax morale: tax evasion justifiable (solid line), tax evasion not justifiable (dotted line), neutral position (dashed line).

To illustrate how to read these graphs, let us examine Panel B, which shows the relationship between an individual's trust in the tax administration and their tax morale, holding all other variables constant. The solid line in Panel $B$ represents the predicted probability that an average individual thinks tax evasion is justifiable, when trust in tax administration is very low $(x$ axis $=1)$, the predicted probability of thinking tax evasion is justified is 0.30 . As trust in the tax administration increases ( $x$ increases) the probability that an average individual thinks tax evasion is justifiable falls, so much so that when trust in the tax authorities is very high $(x=5)$ the predicted probability that an individual will think tax evasion is justifiable falls to 0.08 . This same trend is seen in each panel: high values of the independent variable make the response "tax evasion is justified" less likely (the solid lines have negative slopes on each panel) and the answers corresponding to rejection of tax evasion more likely (the dotted lines have positive slopes for each panel).

\section{Empirical Support for the Hypotheses}

$\mathrm{H} 1$ (trust in government) and $\mathrm{H} 2$ (trust in the tax administration) are supported. Trust in government is statistically significant in all models except the 3-category ordered probit specification of model 3. The result for trust in tax administration is even more robust-it has a positive impact on tax morale across all specifications and is statistically significant at the 5\% level except in the first two OLS specifications, where the statistical significance is lower. The result is robust to variance in sample size. In Panel B (Fig. 2), the positive relation between trust in the tax administration and tax morale is shown. The predicted probability of thinking tax evasion is justified falls from 0.30 , when there is no trust in the tax administration, to 0.08 when there is very high trust. A mirror effect is that the predicted probability of "tax evasion is not justified" increases from 0.09 to 0.22 . A similar pattern in predicted probabilities can be seen in Panel A (Fig. 2) when considering the impact of changes in trust in government on tax morale. The predicted probability of "tax evasion is justified" falls from 0.21 when the respondent expresses no trust in government to 0.09 when there is a great deal of trust in the government. Similarly, the predicted probability of "tax evasion is not justified" rises from 0.25 to 0.45 . 
Community belonging, the variable that captures the social identification with the Latvian polity, comes as significant and positive in models 2,3 and 5, providing support for H3. It only becomes insignificant in model 4 with the inclusion of firm performance between 2007 and 2010. In Panel C (Fig. 2), the plotted predicted probabilities show the positive relation between cultural identity and tax morale. The plot indicates that an owner/manager's identification with Latvian community has the strongest negative effect on the predicted probabilities of "tax evasion is justified". The probabilities fall from 0.47 when the community belonging is weak to 0.12 when it is strong.

Finally, with respect to deterrence factors, there are clear differences between likelihood of being caught (H4) and severity of punishment (H5). While there is significant support for H4 only in model 3, H5 is not rejected as the coefficient on severity of punishment is significant in all models. The positive relationship between tax morale and severity of punishment (H5) is depicted in the plot of predicted probabilities in Panel D (Fig. 2). As beliefs about the severity of punishment increase from "minimal impact" (1) to "serious, possibly leading to business closure" (5), the predicted probability of "tax evasion is justified" falls from 0.29 to 0.08 , and the predicted probability of "tax evasion is not justified" increases from 0.18 to 0.48 .

\section{Estimated Effects of Control Variables}

With respect to controls, performance coefficients come as insignificant [in models (3) and (4)]. There is also no indication that employment size is statistically significant for tax morale. Sectoral differences are not significant apart from the "wholesale" category, which becomes significant and positive in some of the specifications, but this is hard to interpret. Location of the company plays no significant role.

Interestingly, none of the demographic variables such as age, gender, education, that are normally found to be related to tax morale, are significant in this research. A priori, age was expected to have an effect because of differences between those who grew up and lived under communism and those that did not. Ethnicity was also expected to be significant due to divisions between ethnic Russians and ethnic Latvians in Latvia, but we found no support for either.

\section{Discussion and Conclusions}

As argued above, tax evasion matters for development at both the national and the regional level. It may lead to a prisoner's dilemma situation where those who report more of their incomes face unfair competition from those who report less. Therefore, it may result in a vicious circle, where only firms that cannot avoid taxes stay fully in the official sector, and the government may be tempted to increase tax rates to compensate for low compliance. In that case, the situation becomes very difficult for entrepreneurs in the formal sector, who face both competition from the informal economy firms and high costs if they choose to remain fully in the official domain. If such a situation is left unchecked, a more serious crisis may follow, as vividly exemplified by the recent case of Greece (Estrin and Mickiewicz 2012; see also: Bird et al. 2006; Mathias et al. 2015).

These wider considerations motivate this study. The first objective is to focus on analysing the tax morale of business owner/managers and to build on the literature from public finance on tax morale to deepen our understanding of informality in business. The second objective presents a uniform theoretical framework within which the factors which affect the tax morale of business owner-managers may be analysed. By applying Scott's framework, we highlight three different mechanisms-normative, cognitive and regulatory-and by doing so we are able bring together the literature on institutions and tax morale and show that the regulatory mechanisms matter not only for tax evasion but for tax morale as well. Testing this framework in Latvian context provides some tentative evidence on the factors affecting the tax morale of business owner/managers in challenging institutional environments and explains what encourages them to use illegal means to produce their legal products.

We find that tax morale is affected by institutions through all three of the institutional mechanisms identified by Scott (2014): the normative-trust in the government and in the tax system; the cognitive-identification with the wider polity; and the regulatory-perceptions of deterrence. Broadly speaking, tax morale is enhanced by confidence in the ways the taxes are collected and spent. Likewise, robust evidence was found that the evaluation of tax collection as being honest, not corrupt and administered fairly is associated with higher tax morale (Torgler et al. 2008). Taken together, these factors imply that the government, which is by default legal, may or may not achieve social legitimacy. That matters, because in turn, the lack of social legitimacy makes adoption of tax evasion strategies by entrepreneurs more likely.

Legitimacy of the government is enhanced, where citizens execute their rights to decide on fiscal matters in an effective way. Torgler (2005) makes a strong case arguing that "direct democratic rules signal that citizens are neither ignorant nor uncomprehending voters, which creates or maintains a certain social capital stock" (Ibid.: 526). His results for Switzerland demonstrate clearly that the single 
most important factor associated with high tax morale is a decentralised institutional setting, where fiscal referenda serve as a way to establish direct control of citizens over taxes (Torgler 2005, 529). In addition, improving the image of the tax authority, procedural fairness and providing taxpayers with information on how taxes are spent may also be effective ways to combat informality amongst business owner/managers in particular (Alm and McClellan 2012; McGee et al. 2016).

Turning now to the second dimension we emphasised, our results suggest that although business owner/managers may be critical of tax administration and of how tax revenues are handled and spent by the government and may observe non-compliance around, their tax morale may still hold up due to their sense of belonging to the polity and identification with the wider community. This is parallel to the results obtained by Konrad and Qari (2012) on patriotism and national pride as a factor in tax morale, yet we believe that our focus on identity highlights a more fundamental factor as community belonging is a more inclusive form of identification with a country.

Last but not least, we build on limited evidence, which suggests that tax morale may be affected by a self-serving/ egocentric bias (Blanthorne and Kaplan 2008), in line with the regulatory-instrumental institutional logic of deterrence. We find that the perceived consequences of tax evasion affect tax morale, but we add to the literature as our study suggests that the severity of punishment matters more than likelihood of being caught. So far, the evidence on the relative weight of these two factors was only based on experimental studies (for overview, see: Torgler 2002), but we believe our complementary survey-based results are of additional value. Our findings are consistent with the standard-risk avoidance perspective where the expected cost of tax evasion depends on the risk of detection and the size of the ensuing financial losses. It has also obvious policy implications for shaping the parameters of formal policy aimed at reducing tax evasion and avoidance.

At the same time, however, two caveats are worth keeping in mind. First, our results suggest that identity, legitimacy of the government and the tax authorities in particular trump the impact of deterrence. This is consistent with this branch of the literature, which shifts away from the impact of widespread sanctions towards the emphasis on "vertical reciprocity" and "psychological" contract characterising the relationship between the individual and the state (for overview, see: Alm et al. 2010). Second, a heavy-handed use of sanctions may backfire, especially if it is not perceived as fair (e.g. hard punishment of minor tax mistakes versus effective impunity for large-scale transgressors). For better or worse, tax morale will remain "quasi-voluntary"; moreover, excessive use of punishment may crowd-out intrinsic motivation of tax payers, rendering a policy counterproductive (Yew et al. 2015).

In addition to the conclusions related directly to tax morale, the study demonstrates the advantages of adopting a broader institutional theory framework. The informal economy is a key topic of entrepreneurial research where multidisciplinary contributions are particularly relevant. The theoretical framework of this study includes both rational-instrumental elements based on regulatory and formal institutional perspective, as typically applied in economics, and also normative and cognitive perspectives, as promoted by neo-institutionalist sociologists (Scott 2014).

While it has been long recognised that institutions affect individual behaviour and economic outcomes (e.g. North 1990; Williamson 2000), a sharper focus on specific types of agents, such as small business owner/managers, provides a more detailed understanding of how agents' behaviour is shaped by the institutional context. Adopting this approach, this study illustrates how owner/managers' relations with their institutional context affects their behaviour via cognition, values and instrumental/rational calculus. This demonstrates the effectiveness of broadening institutional analysis in business research to include culture and norms, as promoted for example by Harper (2003).

The limitations of the study are evident. The sample size is limited and there is no panel element. Moreover, while the theoretical framework could be applied to other challenging institutional contexts, the results may be to some extent context specific. Compared to other transition countries, Latvia has been found to have particularly low tax morale. Torgler (2012) reports that Latvia had the lowest tax morale of EU new member states in 2008, and the extent of tax evasion contrasts negatively with the two neighbouring Baltic republics, Estonia and Lithuania (Putnins and Sauka 2015). There is also some indication that similarly to the two other Baltic republics and Romania, tax morale actually decreased in Latvia between 1999 and 2010 (Putnins and Sauka 2015; Torgler 2012). This shows why from a policy perspective it is important to understand better the patterns behind these processes.

While we believe that our results have wider significance, Latvia is an interesting context in which to study tax morale, representing a fascinating case of institutional change, where market supporting institutions were rebuilt following the collapse of the Soviet economic experiment. In such environments, the problem that the reforming government faces relates to the inertia in social attitudes (Estrin and Mickiewicz 2011) and social perceptions. Even if the government changes the way it operates, the perceptions of business owner/managers would lag behind and, as expectations in an institutional context always have 
some self-fulfilling prophecies, this makes reform difficult. Special attention needs to be paid to measures restoring trust between officials and owner/managers of private businesses. Unlike East Germany (see: Torgler 2003e), Latvia and other transition countries could not "import" the legitimacy of the government and the tax authorities from elsewhere.

All this calls for more investigation. Possible further studies may also follow Culiberg and Bajde's (2014, p. 271) advice; they emphasise that: “... there is a shortage of tax morale studies that explore ethical decision making as a process composed of multiple steps and determinants". While in some circumstances, entrepreneurs may find ingenious way to organise themselves in parallel to inept state bureaucracies, such organisation comes with high transaction costs. Therefore, the superior, first-best solution is always a sound tax system matched by a government that supports property rights and creates uniform opportunities for business (De Soto 1989, 2001). An informal economy is detrimental to entrepreneurship (De Paula and Scheinkman 2011; Estrin and Mickiewicz 2012), and therefore, understanding the factors that drive tax morale, especially in the business context, is critical.

All procedures performed in studies involving human participants were in accordance with the ethical standards of the institutional and/or national research committee and with the 1964 Helsinki declaration and its later amendments or comparable ethical standards.

Open Access This article is distributed under the terms of the Creative Commons Attribution 4.0 International License (http://crea tivecommons.org/licenses/by/4.0/), which permits unrestricted use, distribution, and reproduction in any medium, provided you give appropriate credit to the original author(s) and the source, provide a link to the Creative Commons license, and indicate if changes were made.

\section{References}

Acemoglu, D., \& Robinson, J. (2012). Why nations fail. London: Profile Books.

Ajzen, I. (2001). Nature and operation of attitudes. Annual Review of Psychology, 52(1), 27-58.

Allingham, M., \& Sandmo, A. (1974). Income tax evasion: A theoretical analysis. Journal of Public Economics, 3(2), 323-338.

Alm, J., \& McClellan, C. (2012). Tax morale and tax compliance from the firm's perspective. Kyklos, 65(1), 1-17.

Alm, J., \& Torgler, B. (2011). Do ethics matter? Tax compliance and morality. Journal of Business Ethics, 101, 635-651.

Alm, J., Martinez-Vazquez, J., \& Torgler, B. (2006). Russian attitudes toward paying taxes-before, during, and after the transition. International Journal of Social Economics, 33(12), 832-857.

Alm, J., Martinez-Vazquez, J., \& Torgler, B. (2010). Introduction: Developing alternative frameworks for explaining tax compliance. In J. Alm, J. Martinez-Vazquez, \& B. Torgler (Eds.),
Developing alternative frameworks for explaining tax compliance (pp. 3-12). London: Routledge.

Alm, J., McClelland, G., \& Schulze, W. (1992). Why do people pay taxes? Journal of Public Economics, 48(1), 21-38.

Alon, A., \& Hageman, A. (2013). The impact of corruption of firm tax compliance in transition economies: Whom do we trust? Journal of Business Ethics, 2013(116), 479-494.

Andreoni, J., Erard, B., \& Feinstein, S. (1998). Tax compliance. Journal of Economic Literature, 36(2), 818-860.

Angrist, J. D., \& Pischke, J. S. (2009). Mostly harmless econometrics: An empiricist's companion. Princeton, New Jersey: Princeton University Press.

Ashforth, B., \& Mael, F. (1989). Social identity theory and the organization. The Academy of Management Review, 14(1), 20-39.

Becker, G. (1968). Crime and punishment: An economic approach. Journal of Political Economy, 76(2), 169-217.

Benk, S., McGee, R. W., \& Yüzbaşi, B. (2015). How religions affect attitudes toward ethics of tax evasion? A comparative and demographic analysis. Journal for the Study of Religions and Ideologies, 14(41), 202-223.

Bird, R. M., Martinez-Vazquez, J., \& Torgler, B. (2006). Societal institutions and tax effort in developing countries. In J. Alm, J. Martinez-Vazquez, \& M. Rider (Eds.), The challenges of tax reform in a global economy (pp. 283-338). New York: Springer.

Björklund, F. (2006). The East European "ethnic nation"-myth or reality? European Journal of Political Research, 45, 93121.

Blanthorne, C., \& Kaplan, S. (2008). An egocentric model of the relations among the opportunity to underreport, social norms, ethical believes and underreporting behaviour. Accounting, Organizations and Society, 33(7), 684-703.

Cohen, J., Manzon, G., \& Zamora, V. (2015). Contextual and individual dimensions of tax payer decision making. Journal of Business Ethics, 2015(126), 631-647.

Culiberg, B., \& Bajde, D. (2014). Do you need a receipt? Exploring consumer participation in consumption tax evasion as an ethical dilemma. Journal of Business Ethics, 2014(124), 271-282.

Davidsson, P., \& Wiklund, J. (2001). Levels of analysis in entrepreneurship research: current research practice and suggestions for the future. Entrepreneurship, Theory and Practice, 25(4), 81-100.

De Castro, J. O., Khavul, S., \& Bruton, G. D. (2014). Shades of grey: How do informal firms navigate between macro and meso institutional environments. Strategic Entrepreneurship Journal, 8(1), 75-94.

De Paula, A., \& Scheinkman, J. (2011). The informal sector: An equilibrium model and some empirical evidence from Brazil. Review of Income and Wealth, 57(1), 8-26.

De Soto, H. (1989). The other path. New York: Harper Collins.

Estrin, S., \& Mickiewicz, T. (2011). Entrepreneurship in transition economies: The role of institutions and generational change. In M. Minniti (Ed.), The dynamics of entrepreneurship. Evidence from global entrepreneurship monitor data. Oxford: Oxford University Press.

Estrin, S., \& Mickiewicz, T. (2012). Shadow economy and entrepreneurial entry. Review of Development Economics, 16(4), 559-578.

Estrin, S., Korosteleva, J., \& Mickiewicz, T. (2013). Which institutions encourage entrepreneurial growth aspirations? Journal of Business Venturing, 28(4), 564-580.

Feld, L., \& Frey, B. (2010). Tax evasion and the psychological tax contract. In J. Alm, J. Martinez-Vazquez, \& B. Torgler (Eds.), Developing alternative frameworks for explaining tax compliance (pp. 74-94). London: Routledge. 
Fishbein, M., \& Ajzen, I. (1975). Belief, attitude, intention, and behavior: An introduction to theory and research. Reading, MA: Addison-Wesley.

Frey, B., \& Torgler, B. (2007). Tax morale and conditional cooperation. Journal of Comparative Economics, 35(1), 136-159.

Gërxhani, K. (2007). "Did you pay your taxes?" How (not) to conduct tax evasion surveys in transition countries. Social Indicators Research, 80(3), 555-581.

Greene, W., \& Hensher, D. (2010). Modeling ordered choices. Cambridge: Cambridge University Press.

Halla, M. (2012). Tax morale and compliance behaviour: First evidence of a causal link. The BE Journal of Economic Analysis and Policy. doi:10.1515/1935-1682.3165.

Hanousek, J., \& Palda, F. (2004). Quality of government services and the civic duty to pay taxes in the Czech and Slovak Republics, and other transition countries. Kyklos, 57(2), 237-252.

Harper, D. (2003). Foundations of entrepreneurship and economic development. Abingdon: Routledge.

Heinemann, F. (2011). Economic crisis and morale. European Journal of Law and Economics, 32(1), 35-49.

Hogg, M., \& Terry, D. (2000). Social identity and self-categorization processes in organizational contexts. The Academy of Management Review, 25(1), 121-140.

Hogg, M., Terry, D., \& White, K. (1995). A tale of two theories: A critical comparison of identity theory with social identity theory. Social Psychology Quarterly, 58(4), 255-269.

Hug, S., \& Spörri, F. (2011). Referendums, trust, and tax evasion. European Journal of Political Economy, 27(1), 120-131.

Ireland, R., Tihanyi, L., \& Webb, J. (2008). A tale of politicoeconomic systems: Implications for entrepreneurship in Central and Eastern Europe. Entrepreneurship Theory and Practice, 32(1), 107-130.

Jones, C., \& Temouri, Y. (2016). The determinants of tax haven FDI. Journal of World Business, 51(2), 237-250.

Kavka, G. S. (1983). When two 'wrongs' make a right: An essay on business ethics. Journal of Business Ethics, 2(1), 61-66.

Kirchler, E., Hoelzl, E., \& Wahl, I. (2008). Enforced versus voluntary tax compliance: The "slippery slope" framework. Journal of Economic Psychology, 29(2), 210-225.

Kolstø, P. (2000). Political construction sites: Nation-building in Russia and the post-Soviet states. Boulder, CO: Westview Press.

Konrad, K. A., \& Qari, S. (2012). The last refuge of a scoundrel? Patriotism and tax compliance. Economica, 79(315), 516-533.

Lago-Peñas, I., \& Lago-Peñas, S. (2010). The determinants of tax morale in comparative perspective: Evidence from European countries. European Journal of Political Economy, 26(4), 441-453.

Long, J. (1997). Regression models for categorical and limited dependent variables. Thousand Oaks: SAGE publications.

Luttmer, E., \& Singhal, M. (2014). Tax morale. Journal of economic perspectives, 28(4), 149-168.

Marien, S., \& Hooghe, M. (2011). Does political trust matter? An empirical investigation in the relation between political trust and support for law compliance. European Journal of Political Research, 50(2), 267-291.

Martínez-Vázquez, J., \& Torgler, B. (2009). The evolution of tax morale in modern Spain. Journal of Economic Issues, 43(1), $1-28$.

Mathias, B., Lux, S., Crook, T., Autry, C., \& Zaretzki, R. (2015). Competing against the unknown the impact of enabling and constraining institutions on the informal economy. Journal of Business Ethics, 2015(127), 251-264.

McGee, R. W., Yoon, Y., \& Li, Y. (2015). The ethics of tax evasion: A comparative study of Chinese and US opinions. Indonesian Journal of International \& Comparative Law, 2(1), 161-186.
McGee, R. W., Devos, K., \& Benk, S. (2016). Attitudes towards tax evasion in Turkey and Australia: A comparative study. Social Sciences, 5(10), 1-13.

Miller, D. (2000). Citizenship and national identity. Cambridge, UK: Polity Press.

Mitchell, R., Busenitz, L., Lant, T., McDougall, P., Morse, E., \& Smith, J. (2004). The distinctive and inclusive domain of entrepreneurial cognition research. Entrepreneurship Theory and Practice, 28(6), 505-518.

Murad, H., Fleischman, A., Sadetzki, S., Geyer, O., \& Freedman, L. S. (2003). Small samples and ordered logistic regression: Does it help to collapse categories of outcome? The American Statistician, 57(3), 155-160.

Murphy, K. (2004). The role of trust in nurturing compliance: A study of accused tax avoiders. Law and Human Behavior, 28(2), 187-209.

Nathanson, S. (1989). In defense of "moderate patriotism". Ethics, 99(3), 535-552.

North, D. (1990). Institutions, institutional change and economic performance. New York: Cambridge University Press.

Pipes, R. (2000). Property and freedom. New York: Alfred A. Knopf.

Preobragenskaya, G., \& McGee, R. W. (2016). A demographic study of russian attitudes toward tax evasion. Journal of Accounting, Ethics and Public Policy, 17(1), 138-207.

Putnins, T., \& Sauka, A. (2015). Measuring the shadow economy using company managers. Journal of Comparative Economics, 43(2015), 471-490.

Putnins, T., \& Sauka, A. (2016). Shadow economy index for the Baltic countries 2009-2015. Latvia: Stockholm School of Economics in Riga.

Sauka, A. (2008). Productive, unproductive and destructive entrepreneurship: A theoretical and empirical exploration. Frankfurt am Main: Peter Lang GmbH.

Schneider, F., Buehn, A., \& Montenegro, C. E. (2010). Shadow economies all over the world. World Bank Policy Research Working Paper, 5356.

Scholz, J., \& Lubell, M. (1998). Trust and taxpaying: Testing the heuristic approach to collective action. American Journal of Political Science, 42(2), 398-471.

Scholz, J., \& Pinney, N. (1995). Duty, fear and tax compliance: The heuristic basis of citizenship behaviour. American Journal of Political Science, 39(2), 490-512.

Scott, R. (2014). Institutions and organizations (4th ed.). Thousand Oaks: Sage.

Stets, J., \& Burke, P. (2000). Identity theory and social identity theory. Social Psychology Quarterly, 63(3), 224-237.

Torgler, B. (2002). Speaking to theorists and searching for facts: Tax morale and tax compliance in experiments. Journal of Economic Surveys, 16(5), 657-683.

Torgler, B. (2003a). Tax morale and institutions. CREMA Working Paper No. 2003-09, Basel. Available at SSRN 663686.

Torgler, B. (2003b). Tax morale, rule-governed behaviour and trust. Constitutional Political Economy, 14(2), 119-140.

Torgler, B. (2003c). To evade taxes or not to evade: That is the question. Journal of Socio-Economics, 32(3), 283-302.

Torgler, B. (2003d). Tax morale in transition countries. PostCommunist Economies, 15(3), 357-381.

Torgler, B. (2003e). Does culture matter? Tax morale in an EastWest-German comparison. FinanzArchiv Public Finance Analysis, 59(4), 504-528.

Torgler, B. (2005). Tax morale and direct democracy. European Journal of Political Economy, 21(2), 525-531.

Torgler, B. (2006). The importance of faith: Tax morale and religiosity. Journal of Economic Behavior \& Organization, 61(1), 81-109. 
Torgler, B. (2012). Tax morale, Eastern Europe and the European enlargement. Communist and Post Communist Studies, 45(1), $11-25$.

Torgler, B. (2016). Tax compliance and data: What is available and what is needed. Australian Economic Review, 49(3), 352-364.

Torgler, B., \& Schneider, F. G. (2007). What shapes attitudes toward paying taxes? Evidence from multicultural European countries. Social Science Quarterly, 88(2), 443-470.

Torgler, B., \& Schneider, F. (2009). The impact of tax morale and institutional quality on the shadow economy. Journal of Economic Psychology, 30(2), 228-245.

Torgler, B., Demir, I. C., Macintyre, A., \& Schaffner, M. (2008). Causes and consequences of tax morale: An empirical investigation. Economic Analysis \& Policy, 38(2), 313-339.

Torgler, B., Schaffner, M., \& Macintyre, A. (2010). Tax compliance, tax morale, and governance quality. In J. Alm, J. MartinezVazquez, \& B. Torgler (Eds.), Developing alternative frameworks for explaining tax compliance (pp. 141-173). London: Routledge.

Warren, E. (2003). Constructive and destructive deviance in organizations. Academy of Management Review, 28(4), 622-631.

Webb, J., Tihanyi, L., Ireland, R., \& Sirmon, D. (2009). You say illegal, I say legitimate: entrepreneurship in the informal economy. Academy of Management Review, 34(3), 492-510.
Wei, W., \& McGee, R. W. (2015). Gender and attitude toward the ethics of tax evasion: A comparison of European and Asian views. Journal of Accounting, Ethics and Public Policy, 16(4), $735-764$.

Welter, F. (2012). All you need is trust? A critical review of the trust and entrepreneurship literature. International Small Business Journal, 30(3), 193-212.

Welter, F., \& Smallbone, D. (2011). Institutional perspectives on entrepreneurial behaviour in challenging environments. Journal of Small Business Management, 49(1), 107-125.

Wenzel, M. (2005). Motivation or rationalisation? Causal relations between ethics, norms and tax compliance. Journal of Economic Psychology, 26(4), 491-508.

Wiklund, J., Davidsson, P., \& Delmar, F. (2003). What do they think and feel about growth? An expectancy-value approach to small business managers' attitudes towards growth. Entrepreneurship Theory and Practice, 27(3), 247-269.

Williamson, O. (2000). New institutional economics. Journal of Economic Literature, 38(3), 595-613.

Yew, B., Milanov, V. B., \& McGee, R. W. (2015). An analysis of individual tax morale for Russia: Before and after flat tax reform. International Business Research, 8(1), 60-80.

Yitzhaki, S. (1974). A note on income tax evasion: A theoretical analysis. Journal of Public Economics, 3(2), 201-202. 